\title{
ЯЗЫКОЗНАНИЕ
}

UDC 81.33

DOI: $10.17223 / 19996195 / 46 / 1$

\section{AN ARTISTIC IMAGE METAPHORICITY: CULTURAL MEMORY AND TRANSLATION}

\author{
V.A. Razumovskaya, E.B. Grishaeva
}

\begin{abstract}
The article presents a complementary semantic-semiotic analysis of an artistic image in the framework of a literary text. The analysis is followed by post-translation descriptions. Being generated and functioning within a literary text an artistic image is considered to be an extended metaphoric formation primarily destined to fulfill the aesthetic function. Particular attention is paid to the cultural information and memory embodied in a unique cultural code presented in an artistic image and closely connected with its metaphoric characteristics. The present research was conducted on the material of the "strong" text of the Russian culture - "The Master and Margarita" by M. Bulgakov. The artistic image of Bulgakov's tom-cat Behemoth is a heterogeneous metaphoric formation combining the cultural memory of a Biblical monster Behemoth, zoo-metaphorical characteristics of a hippopotamus (as a real fauna representative) and various connotations of a black tom-cat in its real and mythological hypostases. The research methodology assumes integrated analysis combining mythopoetic, hermeneutic and comparative methods. In the situation of literary translation, a literary image can be considered as a regular unit of translation, the reconstruction of which in "other" languages and cultures requires special translator's decisions and application of effective translation techniques and strategies.

Keywords: "Strong" text; artistic image; cultural information and memory; cultural code; metaphor; aesthetic effect; intertextuality; "The Master and Margarita"; Behemoth; cognitive equivalence.
\end{abstract}

\section{Introduction}

Any literary text is the unique result of individual perception, image comprehension and artistic reflection of the real or fiction life. Such type of a text is mainly aimed at an aesthetical influence on a potential reader through the form-content sets of its information. Understanding metaphors in literary texts are of extreme importance for the artistic information comprehension [1].

That is the reason why the information space of any literary work, by extension, can be defined as a continuous metaphoric space. There is no doubt that depicting the real and fiction life in the artistic form an author necessarily reflects his own view on the world, expresses his personal experience and attitude to the describing topics through a combination of real facts and artistic fiction created inside his message. A fundamental truth of any 
literary text is the aesthetic information based on the inherent metaphoricity of the author's consciousness making the text aesthetically valuable and intended to endue it with the aesthetic force, with the ability to fulfill the aesthetic function - the predominant function of any literary text. In terms of the content, any literary work (both poetic and prosaic one) represents a unique artistic image formed mainly with regard to the main universal human values, standards and notions that allow to state an axiological attitude towards the objective reality and introduce diverted ontological categories through the concrete, sensual and visual experience and feelings [2]. Traditionally, the powerful ("strong") literary images are created in "strong" texts which are characterized by a high energetic (and, thus, aesthetic) potential and wide readership. The "strong" texts keep sharing their high aesthetic energy to their readers and respectively receiving the readers' energy multiplied due to the emerging information resonance [3]. Pointing out the inherent metaphoricity of a whole "strong" text as an explicated artistic image, it is necessary to note the importance of recognizing the aesthetic significance and metaphoricity of certain literary images integrated into the artistic texture. As a regular artistic universal, the artistic image has a literal meaning and describes a certain generalization and expansion degree [4]. Emerging from a sensual image, it obtains semiotic potential and generates numerous signs and complex semiotic notions the structure of which is formed by the interplay of two essentially different plans, i.e. of the content and expression ones [5].

\section{Methods of research}

The comparative, mythopoetic, hermeneutic and descriptive methods were mostly used to obtain relatively reliable and convincing results in the present research. The comparisons of the selected literary original text by M. Bulgakov and its secondary foreign languages variants (mostly English and Chinese) as well as comparisons among existing translations created in one target culture were performed. The comparative method is considered to be an effective technique for studying the secondary variants of a literary original by performing a feature-by-feature comparison of two or more literary texts within one broad center of translation attraction. Almost complete absence of translator's discourse with the translator's reasoning concerning his/her final decisions determined the descriptive character of the paper. The results of the conducted comparative analyzes were predominantly described in linguistic, cultural and translation aspects.

\section{Basic assumptions: "The Master and Margarita" as a "strong" text of the Russian literature and culture}

One of the prominent and widely-known (following Natalya Kuzmina's terms - "strong") literary texts in the Russian literature and culture is, 
undoubtedly, "The Master and Margarita". The last novel by Mikhail Bulgakov which was completed in 1940 (the year of the author's death) is fairly considered as one of the most outstanding works of the $20^{\text {th }}$ century in the Russian culture. The novel has repeatedly entered the short list of literary works of all times: according to "La Monde" in 1999, to BBC's list in 2003 and to "Nezavisimaya Gazeta" (English - "The Independent Newspaper") in 2010. Being published in 1966-1967 for the first time (more than a quarter century after the writer's death), just in 1967 the novel was focused by the foreign-language translations. The high aesthetic and artistic value of the text, its original individual poetics and style, constant interest of the readers to the compound plot and bright and memorable Bulgakov's characters determine that permanent generation of numerous secondary texts by "The Master and Margarita" original. Thus, following the interlingual translation defined by Roman Jakobson as "translation proper", it can be noted that, according to our records, the modern world knows several English translated versions of that cult novel ${ }^{1}$. Other interlingual translations are represented by numerous works in German, French, Spanish, Polish and Ukrainian as well as in many other modern languages.

A perfect illustration of such a constant appearance of translations within one culture is the historiography of Japanese translations. The first of them (by Yuko Yasui) was completed in 1969 and published under the title “The Devil and Margarita” (悪魔とマルガリータ). This translation was intermediated thought the Italian version by Vera Dridso ("Il Maestro e Margherita") published already in 1967. In 1977 Tadao Midzuno presented his translation to the Japanese readers and published it under the traditional title which corresponded to the original version: "The Master and Margarita" (巨匠とマルガリータ). Midzuno's translation was included into the Japanese collection of the world's literature. The third Japanese version of the novel “The Master and Margarita” (巨匠とマルガリータ) by Ayko Hoki appeared in 2002, in two volumes.

This novel remains a great interest for the intersemiotic translation (following Roman Jakobson). There are numerous screen adaptations of Bulgakov's text. The first one was "Pilate and Others" by Andrzey Wajda (1971, FRG) which provoked a mixed respond of the viewers and critics. The film loses the Moscow part of the plot, and the Yershelaim events are replaced in the modern city environment. A year after (in 1972), there was an Italian-Yugoslav screen release directed by Alexander Petrovic and from 1988 to 1990 - Polish television series (4 episodes) by Maciej Wojtyszko. In 1990, in Hungary, Andras Szirtes made the film "After the Revolution" based on the life of Hungarian writer, an emigrant, and narrated by his cat. In 1991 Oldrĭch Daněk, a Czech film director, created "A Day of the Life of Pontius Pilate". In 1992, the British audience learnt about "Incident in Judea", a TV-play by Paul Bryers, which, similar to Wajda's film, covered on- 
ly the Yershelaim part of the novel. In 1994 Yury Kara screened a fourseries which became available only in 2011; in 1996 - a TV-play by Sergey Desnitskiy; in 2005 - another Hungarian narrative short (26 min.) starred with the Russian actors (directed by Ibolya Fekete). The last Russian screened version ("The Master and Margarita") was created by Vladimir Bortko in 2005. In Italy, Giovanni Brancale shot "The Master and Margarita" which was premiered only in 2011 in Florence. The novel has also been animated in cartoon for several times. Besides, it has also been embodied in numerous theatrical productions. The popularity of performances based on the novel's plot is evidenced from the fact that in 2011-2013 they were shown on the stages of more than 40 world's theatres annually [6]. Thus, Roman Viktyuk suggested another version for the title - "The Master and Margarita, or Ivan Bezdomniy's Dreams"; in Moscow Satire Theatre - "That Being Said, Schizophrenia". Tambov welcomed a musical "The Master's Script" - the first one based on the novel's drafts (2009). Gesher Theatre (Israel) performed "The Devil in Moscow" in Tel Aviv (2001) and Tallinn (2004). The class of intersemiotic translations of the novel also include operas, symphonies and music compositions as well as ballets. In the context of arts they are also represented by illustrations and graphics. Of particular interest is a graphic expression in the form of theatre posters and book covers as well as in photos (in the latest photo project the role of Bulgakov's Margarita was performed by Isabelle Adjani). In sculpture the novel's translations are shown through the works by Alexander Rukovishnikov (Bolshaya Molchanovka Street in Moscow). The occurrence of new types of the information carriers has been followed by the development of sound versions of the written text, i.e. of audiobooks.

The above information concerning the translations (in the broad sense of the term) does not purport to be a comprehensive one, but it clearly demonstrates that the "strong" text is keen on self-recurrence and always generates its secondary variants creating multicomponent centres of translation attraction [7]. Concerning the field structure of such translation attraction centre, the literary source-text serves as a core-stimulus of the traslatability field involving the central part which unites all the current and existing. The periphery includes those translations, which are not relevant due to their obsolescence or low quality. The prospective (potential) part of the field is intended for a hypothetically possible translations which may well appear in the future.

\section{Literary text information: ambiguity, cultural information and memory}

The intention and ability of "strong" texts of literature and culture to self-recurrence can be primarily explained by their information characteris- 
tics. Thus, the aesthetic information and related cultural information and memory form some undeveloped, undescribed and, consequently, always ambiguous content of a literary text. The information ambiguity, first and foremost, determines high degree of variability in perception and decoding of a literary text content in the course of its comprehension and generates infinite possibilities in interpretation of a source text both by the "native" readers (living within the source culture and language), "foreign" ones (living within the recipient culture and language) and by translators ("superreaders" living at the border between two cultures and languages). Thus, such regular "imitativeness" and "extendibility" of a literary text over the whole its "life" is explained by its information ambiguity, which is one of the most important information characteristics of a literary text as well as one of the key categories of literary translation. It is the ambiguity that is directly linked to such new categories of the literary translation studies as a source text "inexhaustibility" (the possibility of practically endless reinterpretations of a source text information within the processes of its decoding and comprehension) and translation multiplicity (the text ability to generate multiple secondary variants through intralingual, interlingual and intersemiotic translations). A special part in the information space of the literary text is occupied by the cultural information and, particularly, by such its type as cultural memory, i.e. relatively new scientific notion which means an external assessment of the memory and includes temporal and social aspects alongside with the social tradition and communication [8].

Jan Assman, a German egyptologist, historian of religion and culturologist, refers the phenomenon of cultural memory to the formation and preservation of a collective identity ("us-identity") and assumes that, namely, through the cultural memory, which crucially serves as an extremely important connective structure of each particular society, the circulation, preservation and transfer of the cultural sense is performed. By defining the cultural memory as a specific form of the collective memory, Jan Assman interprets this phenomenon using the notion of "remindful culture" meaning collective or group memory, which determines the collective identity and has a super-individual nature. The same understanding of the cultural memory is well represented in the works by the Russian semiotic and culturologist Yury Lotman, who considers "the cultural memory and the memory of culture" [9].

The cultural memory as a special type of the cultural information is an indirect, frequently changed and sometimes very much distorted information about the past events. Analyzing this phenomenon we should take into consideration the permanent mythologization of historical events, places, phenomena and characters. The results of mythologization are directly reflected and included into the information space of folk songs, tales, legends, anecdotes and other spoken and written texts, that in any cases leads to the creation and preservation of such inaccurate and distorted cultural information. 
The cultural memory recording can be regularly exemplified in ancient sacred or philosophical texts. It is also permanently represented in literary texts (obligatorily in "strong" ones), what has already been addressed in some papers $[10,11]$. In a literary text, the cultural memory is expressed through the signs of different levels. Particularly, such signs include culturonyms, i.e. linguistic (mostly lexical) units assigned to the cultural elements and classified into polyonyms, idionyms and xenonyms [12]. The culturonyms often perform as the literary translation units concerning which translators make the decisions to translate. Crucially, as hypo-units, the culturonyms take part in the construction of a complex multileveled unit (hyper-unit) of a literary text - an artistic image.

\section{Behemoth - the brightest artistic image of "The Master and Margarita"}

This work analyses the culturonym, which is closely related to Behemoth - a tom-cat and one of the infernal characters in Mikhail Bulgakov's "The Master and Margarita". This character, a member of Woland's entourage, is one of the most famous and memorable among others, though it is described as a minor one. Contrary to a certain sketchiness and incompleteness of the main characters (of the Master, mainly), the cat's image is described with many catchy features, with the smallest details which contribute to the most complete and precise comprehension of the artistic image. Behemoth's popularity is also illustrated by the fact that the covers of almost all English and others translations of "The Master and Margarita" show the very image of this black cat. Let us remind that the book cover graphics can also be considered as a case of intersemiotic translation.

The research methodology assumes integrated analysis combining mythopoetic, hermeneutic and comparative methods. These methods and their complementary applying help to reveal the archetypical meaning of the image, realize the nature and basis of its creation and identify the specificity of original (Bulgakov's) and secondary (translators') interpretations of the tom-cat's image.The members of the Devil's entourage complete one of the main characters of the novel - the infernal Woland (Devil) - and symbolize different human sins and passions. In the beginning (the chasing episode, the Odd Flat episodes) Behemoth ("a moggy", "a big cat") appears as a big black cat wearing "a daring horse whiskers", walks on two legs, can speak, travels on a tram trying to buy a ticket, drinks alcohol, eats pickled mushrooms, fixes a primus and philosophizes a lot. In a human form, Behemoth shows up as a small fat man with a face resembling a cat's muzzle. The third of the Behemoth's appearances is described in the flight under the moon light in the final part of the novel, when Behemoth comes across the readers as a thin young boy, an evil page ${ }^{2}$. Time and again, Bulgakov marks that the cat-shapeshifter plays the role of Woland's favorite jester. As well as many other artistic images in this symbolically complex novel, Behemoth's char- 
acter and the episodes with his participations link the text to a number of precedent texts of the world's literature and culture. A special place among them is taken by one of the "strongest" world's texts - the text of Bible. It means that the formation of the artistic image is closely connected with the issues of intertextuality which provides not only the heterogeneity of the image under study but also its polygenicity. The process of the generation of the artistic image is determined by the interaction of various religious, mythological and literary pretexts in the broad information space of the novel.

To create Behemoth's bright artistic image it is highly important to choose the appropriate name. We know that in "The Master and Margarita" the characters are named after long and doubtful thinking of the author that is reflected in a plenty of personal names lists found in the novel's drafts. Finally, Bulgakov chose the name guided by a sophisticated multifaceted association and semantic structure of the Russian lexical unit "behemoth" (Russian "бегемот"). According to the dictionaries of the Russian language, the lexical unit "behemoth" ("бегемот") primarily means a big cloven-hoofed mammal (lat. Hippopotamus amphibius). This unit was borrowed into Russian in the second half of the $18^{\text {th }}$ century presumably from one of the European languages (very likely, from French - "behemoth" or German - "Behemoth") which had taken it from the ancient Hebrew sacred text (Latin "behemoth" from the Ancient Hebrew "behemoth" meaning "animals"). In the apocryphal Book of Enoch (Old Testament) the unit nominates a big and strong animal. Together with "behemoth", the modern Russian language contains another lexical unit - "hippopotamus" ("гиппопотам") which also entered the Russian language system in the $18^{\text {th }}$ century and originated from the Greek word "hippopotamos" ("river/water horse"). The unit was borrowed from Greek into Latin and, further, into many European languages. Interestingly, the ancient Egyptians called a mammal as a "river pig". In Arabic this animal is nominated as فرس النه (English - "Nile horse"), and Vladimir Dal's dictionary includes such word combination as a "swamp cow" considered as a full synonym for "hippopotamus".

Thus, to nominate this big-sized mammal the modern Russian language uses two lexis units at the same time. The association experiment on the synonyms "behemoth' and "hippopotamus" has resulted in the fact that these units construct a synonymous pair, where "behemoth" can be defined as a themeword and "hippopotamus" as a marked member. With the help of the experiment we have discovered that the Russian native speakers interpret the word "hippopotamus" mainly through the word "behemoth" and not vice versa. Both lexical units are featured by a high percent of similar reflex-words, which means the strong similarity of their associative fields, though, according to the research data, the associative field of "behemoth" is much more diverse. "Behemoth" is linked not only to the notion of a particular animal, but also to a scary beast in general [13], which is especially relevant when analyzing the artistic image of Bulgakov's Behemoth cat. 
To denominate this mammal, most of the modern European languages use the units originated from the Greek word "hippopotamos" and, further, transliterated: "hippopotamus" (English), "ippopotamo" (Italian), "hipopótamo" (Spanish), "hippopotame" (French). The German language has a semantic loan-translation from Greek - "Flußferd" (meaning "river horse") - and as structurally synonymic unit - "Nilpferd" ("Nile horse").As the defining and etymological dictionaries of the Russian language have shown, the word "behemoth" alongside with its reference to the animal (not an endemic one in the Russian fauna) has the following meanings: "a blimp; clumsy person" (labeled as "hum"); "beast, monster". The first meaning is considered by the analysts as related to the group of nationally specified zoomorphisms of the Russian language [14].

This group consists of the units not having an English equivalent, which may well be used to describe a big and clumsy person. The second meaning directly refers to the Biblical text. The Biblical Behemoth is depicted as one of the creatures (as well as the Leviathan) which the God demonstrates to Job to prove His mighty in the Book of Job (Chapter 40): "Look at Behemoth, which I made along with you and which feeds on grass like an ox. What strength it has in its loins, what power in the muscles of its belly! Its tail sways like a cedar; the sinews of its thighs are close-knit. Its bones are tubes of bronze, its limbs like rods of iron. It ranks first among the works of God, yet its Maker can approach it with his sword. The hills bring it their produce, and all the wild animals play nearby. Under the lotus plants it lies, hidden among the reeds in the marsh. The lotuses conceal it in their shadow; the poplars by the stream surround it. A raging river does not alarm it; it is secure, though the Jordan should surge against its mouth. Can anyone capture it by the eyes, or trap it and pierce its nose?"3. There is a widely known picture "Behemoth and Leviathan" by W. Blake (1802-1804) illustrating the Book of Job. Behemoth is also mentioned in the Book of Enoch (LX): "And on that day were two monsters parted, a female monster named Leviathan, to dwell in the abysses of the ocean over the fountains of the waters. But the male is named Behemoth, who occupied with his breast a waste wilderness named Disdain, on the east of the garden where the elect and righteous dwell, where my grandfather was taken up, the seventh from Adam, the first man whom the Lord of Spirits created"4. Thus, the Old Testament includes the proper name "Behemoth" used for one of the mythical animals described in the Book of Enoch as a shape shifter sea creature. For the readers familiar with this biblical monster through the unit "behemoth" meaning one of the giant animals, the name of Bulgakov's cat is understood through the "strong" metaphor of evil. It is important to add that within the demonological tradition Behemoth is seen as a demon of gluttony, i.e. one of the Seven Deadly Sins.

In Bulgakov's novel the big cat is rightly named as Behemoth, and not as Hippopotamus. Although, both of these units metaphorically express the 
meaning "very big" in the Russian language and both of them have practically identical aesthetic power. However, the cat named as Behemoth is not simply a big-sized cat, but also a glutton-cat that is quite convincingly shown within the episode in Torgsin (Russian acronym for "trade with foreigners") $)^{5}$. On the other hand, it is a demon-cat. Thus, to generate the metaphor of evil from the synonymic pair "behemoth - hippopotamus", the author of the original text reasonably choose the unit "behemoth". Therefore, we can assume that Bulgakov's artistic image is marked by a polymetaphoricity occurring upon the mix of three notions in the space of one image: "a giant cat", "a glutton-cat" and "a demon-cat".

The image of Behemoth is based on the author's profound knowledge in the sources related to the problems of demonism $[15,16]$. Particularly, it is the essay written by Ivan Porfir'ev in 1872 "The Apocryphal Tales about the Old Testament Persons and Events". The Behemoth's demonism and infernality, explicated by his name and affiliation with Woland's entourage, are combined with the humor and comic behavior of the character that explains its vivid heterogeneous nature. Thus, the proper name "Behemoth" expresses all the following meanings in one: "a giant creature", "a beast or monster" and "a demonic creature". The character's duality, in turn, is explicated by its double nomination: the cat as an animal and its naming as "Behemoth" possessing an extremely strong information and associative field. Behemoth-cat's image as well as the language signs marking this character, complementary combine the cultural memory reflected in the myths ("cat") and the cultural memory reflected in the sacral texts ("Behemoth"). Thus, in the folk beliefs, fairy-tales and folk tales the cat accompanies the puck and, as a rule, lives in the witch's house. A symbolically important meaning is given to the black color since just very that kind of cat is traditionally described as a part of the evil spirits. The black cat can be seen nearby a number of mythological and folk characters (devil, deuce, witch, goblin, and puck). As the folk mythology demonstrates, the deuce can become a cat, and the puck screams in the cat-way [17].

In the folklore, the cat also has numerous incarnations. The main among them is the demon-cat, the shapeshifter cat or a grisly and ill-fated creature. In this context, once and again, we can conclude on the polymetaphoricity of Behemoth's image. Thus, its double demon metaphoricity is developed through the combination of the cat and behemoth metaphors in one image's information space. To express his creative ideas and thoughts, Bulgakov uses a diverse individual zoomorphic code (including an ornithological one as well) [18]. Yet, the use of Behemoth-cat in the cult Bulgakov's novel is understood as a logical continuation of the literary tradition mentioned above. 


\section{The artistic image of Bulgakov's Behemoth as the unit of literary translation}

In the case of literary translation the translator is challenged at not only searching for the most appropriate foreign language equivalents for the units forming the artistic image within the source text, but also at rebuilding in the target text all the explicit and implicit ties peculiar to the source units. The scholars keep constantly turning their attention on the issues of metaphor translation [19-21]. A metaphor as an object of translation is a challenge for a translator: "Unfortunately, the translator has to suffer twice when he approaches these metaphoric expressions. First, s/he has to work out their figurative meaning intralingually (i.e. in the language in which a metaphor is recorded). Second, s/he has to find out equivalent meanings and similar functions of these expressions in the TL" [22].

The choice of efficient translation strategies is directly linked to the problem of translation unit identification - a classical and "eternal" question in the translation studies. Concerning the literary translation studies, we must take into consideration such an unique type of translation units as the artistic image. Assuming the artistic image as an independent unit is reasoned by the fact that concerning its "transcreation" in the target language, culture and literary system a translator has to take unique decisions for its decoding and transcoding. "Transcreation" of the artistic image in the course of literary translation remains a complex, analytical-synthetic procedure intended with the source information decoding and recoding by the means of the target language and culture. The heterogeneous nature of the artistic image as the translation hyper-unit determines the variety and a certain amount of the translation hypo-units concerning which the translator also makes their decisions to make the translation and how to make it. Of particular relevance in that re-construction of the source artistic image is recreation of the cultural information and memory represented in the semantics of the artistic image's elements, and, thus, of the translation hypo-units as well. Since we have recognized the artistic image as the translation unit, the translator's main goal is to achieve that highly accurate reconstruction of the mechanism of generation of the information-ambiguous and aesthetically important unit in the literary text mainly represented by the artistic unit.

Let us take up the examples of Behemoth's image reconstruction in different translated versions. The cat's proper name, undeniably, plays an important role in Bulgakov's artistic character creation, and, thus, constitutes the translation hypo-unit. "Behemoth" is a metaphor-name. It is extremely important to admit that this metaphor is a multileveled one, the comprehension and accurateness of which depends of the information reserve and cultural experience of a potential reader. Thus, for those readers of the source and translated texts who have the cultural information and memory about the 
Old Testament's demonic characters obtained through their family and school education as well as through their self-development, this metaphor means an explicitly negative information about the gluttony and directly refers to the concept of sin and fear. However, those associations of the unit "behemoth" caused by its biblical origin do not actualize in perception and decoding of the novel's information by the readers who are not familiar with the Old Testament and, as such, with Behemoth as the biblical character. In this case, the text perception may awake those associations related only to one of "behemoth" ("behemoth" and "hippopotamus" are the synonyms in the Russian language) meanings denominating a real, not a mythic, animal or human. Thus, the name "Behemoth" contains the mythological and demonological types of information included into much wider continuum of the cultural information and memory.

In the commentary on the English translation made by D. Burgin and K. O'Connor, a number of explanatory remarks accompanies the cat's name. According to the first of them, "Behemoth" is the biblical Hebrew name (taken from the Book of Job) given to the Devil's assistant for some magic actions. The second remark refers the English readers to "Faust" by J. Goethe, which remains the precedent text in relation to "The Master and Margarita". In the German text (Scene 3, The Study) a Black Dog is compared with the hippopotamus: "The dog's growing big and tall. He rises powerfully; it's no doglike shape I see! What a spectre I brought home! Like a hippo in the

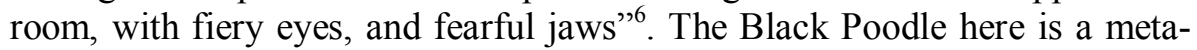
phor, which symbolizes the powers of darkness and evil. Having came back as a terrible and huge behemoth (of course, it is the behemoth-demon, and not the animal), the Black Poodle turns into Mephistopheles now when Faust starts translating the New Testament. Let us recall, in Bulgakov's novel, Goethe's Black Poodle is represented as the handle of Woland's walking stick and in the Devil's Spring Ball (Satan's Rout) as an extended metaphor and allusion: the image of the black poodle is on Margarita's chest and on the small pillow put under her foot. Thus, in the artistic space of these three greatest books (the Bible, "Faust" and "The Master and Margarita") Behemoth's image resembles some metaphoric clamp. It is noteworthy that the image of Behemoth-demon has been used time and again in the modern fiction: "The Battle" by R. Sheckley (1954), "Timm Thaler, or the Traded Laughter" by James Krüss (1962); "The Erl-King” by M. Tournier (1970), "Basileus" by R. Silverberg (1983), "War of the Mage" by Nick Perumov (2003-2006).

In most of the English translations, the translation commentaries are either absent or do not explain the cat's proper name. We are likely to assume that for the English-speaking readers the name-metaphor of Bulgakov's cat evokes solely the Old Testament meaning. Such conclusion is reasoned by the fact that the English versions of the Bible include the unit "Be- 
hemoth" undoubtedly relevant for the readers who are aware of the Old Testament. Still, at the same time, the English translations completely lose the zoomorphic meaning of the name since to nominate the real mammal in the English language one uses the Greek-originated unit "hippopotamus".

Some interesting observations on transferring the artistic image of Bulgakov's cat in the translation allow carrying out a comparative analysis of the Russian text and its translations into originally unrelated and "NonChristian" languages and cultures. In that context, comparing two Chinese variants (the first is a full-text translation made by Qian Chang ${ }^{7}$ in 1987 and one of the contemporary translations by Gao Huiqun ${ }^{8}$ published in 2007) reveals that the name Behemoth is translated in these texts by the semantic approach. At the same time, in Qian Chang's work the character is named only as Behemoth (河马 - River Horse), and in Gao Huiqun's variant mainly as the cat (黑猫 - Black Cat). A later translation also includes a phonetic variant of the word “behemoth” - 别格莫特 - remarking that the Russian original text the character is called Behemoth [23]. This translation comment links to the text of the Chinese translation of the Bible that enables the interested reader to get that information about the demonic nature of the character missed in the translation and better comprehend the artistic image. The comparative analysis of the source text and its two Chinese translations illustrates that significant deformation of the original artistic image since the absence of the Christian cultural memory in the Chinese culture makes it impossible to preserve the demonic cultural metaphor within the translation and transfers only the zoomorphic one. This case of decoding / non-decoding of the artistic image metamorphose can be described by Yury Lotman's statement: "To make the artistic communication act occur, the author's and reader's codes must build intersecting sets of the structural elements" [24. P. 37-38]. In this context, a communication failure emerges at the national and cultural level. Considerable difficulties in the translation of "The Master and Margarita"s metaphoric richness by the means of the Chinese language have been observed in a special recent research [25].

To create the artistic image of Bulgakov's character it is highly important to respect Behemoth's cat form as well. The comparison of the Russian and English lexis demonstrates that the Russian zoonym "кот" directly matches the English "cat". Still, in this interlingual and, consequently, intercultural synonymous pair one can trace a vivid lexical asymmetry in the sense of gender: "кот (male); кошка (female)" - "cat". The original novel includes only the unit "кот" which has an unequivocal gender characteristic for the male creature. The unit "кот" remains a part of a dichotomous pair "кот - кошка". The Russian linguoculture is marked by particular names for the male and female referents, while the English one mainly uses a common generic name [14]. Given the necessity, the English texts can contain such 
elements which clarify the animal's gender by implying a corresponding personal pronoun ("he-cat", "she-cat") or proper name ("tomcat" "pussy cat") into the nominative unit. As the analysts say, the process of fauna nomination in the English language to differentiate the animals one from another is quite complicated, and when using the animals' names to characterize the people, not the gender, but the revealed associations are important. The personification of animals and their translation from English into Russian was the object of a special research [26]. The Bulgakov's nominations of the cat can serve as the interesting material for the study of translations of Russian animal personification into various foreign languages.

The comparative analysis of the original text and some English and Chinese translations revealed the similarities and inconsistencies, which can be found between the Bulgakov's artistic image and its interlingual interpretations. The heterogeneous nature of Bulgakov's Behemoth as a heterogeneous metaphoric formation determines this artistic image to perform the role of hyper-unit of a literary translation. A set of hypo-units constructing the hyper-unit of the image should be reconstructed in the secondary texts. The degree and accuracy of hypo-units preservation in the secondary texts of translations determine the accuracy and completeness of the hyper-unit (an artistic image) reconstruction.

Assuming a metaphor to be tool of people's experience conceptualization that gave rise to the cognitive theory of metaphor [27], the cognitive approach to the study of the artistic image in a translation aspect is considered to be appropriate and effective one. It is extremely important that the researchers highlight that despite the large amount of literature available on the literary aspects of metaphor, very litter research can be found on translation aspects of metaphor, especially cogno-cultural translation type [22]. The doubts concerning the translatability of metaphor are often presented in the scientific discourse [28] with different degree of optimistic and pessimistic approach: "what determines the translatability of a SL metaphor is not its 'boldness' or 'originality', but rather the extent to which the cultural experience and semantic associations on which it draws are shared by speakers of the particular TL" [29. P. 28]. In this case, it is more reasonable to consider not the absolute untranslatability of metaphors, but the limits of their translatability [30] and to take into consideration a sort of translatability scale. It means that some metaphors are quite easy to reconstruct in the target language and culture and some metaphors are not. As for the cultural experience, we consider the concepts of cultural information and memory to be appropriate in this context. Assuming the direct culture influence on metaphors, we treat a metaphor as an important the cultural object and in the aspect of literary translation - the regular unit of translation.

Fully agreeing with the already classical statement that "ordinary conceptual system is fundamentally metaphorical in nature" [31, 32] and follow- 
ing the cognitive approach to the study of cultural aspect of translation in general [33] and to the translation of metaphors in particular [34, 35] and we consider that the category of cognitive equivalence can be used for the purpose of comprehension of artistic image in the framework of a literary text and its multiple reconstruction in translation. Exploring relationship between metaphoricity of the Behemoth artistic image, its resources of dominant information and memory with regard to the ways of its "saving" in the process of literary translation we should take into consideration the blending of cross-language and cognitive types of equivalence. The key challenge for the translators of the considered artistic image is its blended universality and uniqueness distorting the metaphor meaning and affecting the understanding by the readers.

\section{Conclusion}

The semantic-semiotic analysis of the artistic image of Bulgakov's Behemoth in the framework of one of the "strongest" text of Russian literature and culture "The Master and Margarita" revealed image's high degree of heterogeneity and polygenicity. Assuming the idea that the information space of any literary work can be defined as a continuous metaphoric space, the artistic image of the tom-cat named Behemoth is considered to be an important metaphoric construct (hyper-unit) created by merging of a number of metaphoric entities (hypo-units): the biblical metaphor derived from the Old Testament demonic creature of Behemoth whose name was used by the novel's author to nominate the bright and memorable infernal personage; the zoo-metaphor derived from the lexical unit nominating in the Russian language a real big-sized mammal; the feline zoo-metaphor. The evident image's duality (or even triplicity - Behemoth, a hippopotamus and a black tom-cat) generates extremely strong and multidimensional artistic information and associative field.

The Behemoth-cat's image as well as the language signs denoting this artistically relevant character (his appearance, behavior and speech) are complementary combining the cultural memory reflected in the sacral texts ("Behemoth") and the cultural memory broadly presented in the folk art and myths ("cat", especially black one). The post-translation descriptions of Behemoth's interpretations in several English and Chinese translations indicate the possibility of various interpretations of the image resulting into its regular multiplicity. Its heterogeneous nature as the translation hyper-unit determines the variety and a certain amount of the translation hypo-units concerning which the translator also makes the decisions to make the translation and the choice of appropriate translation strategies and techniques. For the "successful" reconstruction (recreation) of the source artistic image of particular relevance is the accurate recreation of the cultural information and memory 
represented in the semantics of the original artistic image's elements, and, thus, of the whole translation hypo-unit as well. Since we have recognized the artistic image as the translation unit, the translator's main goal is to achieve that highly precise reconstruction of the generation mechanism of the information-ambiguous and aesthetically important unit in the secondary literary text mainly represented by the artistic unit. Particular important role in the comprehension of the original cultural code and metaphoricity of the artistic image by the text readers and translators (as "super-readers") plays the cognitive approach to the information of the metaphoric image. The cognitive tools are also extremely relevant and effective concerning the category of cognitive equivalence, which can be used for the purpose of the artistic image reconstruction in translations as the secondary texts of "The Master and Margarita" and the recreation of the original text and artistic image "strength". The main translator's goal with regard to the artistic image of Bulgakov's Behemoth is to reach the aesthetic effect of the reconstructed image similar to the original one.

\section{Notes}

${ }^{1}$ Bulgakov M. The Master and Margarita. Translated by Michael Glenny. London : Collins and Harvill, 1967; Bulgakov M. The Master and Margarita. Translated from the Russian by Mirra Ginsburg. New York : Grove Weidenfeld, 1987; Bulgakov M. The Master and Margarita. Translated by Richard Pever and Larissa Volokhonsky. London : Penguin Books, 1997; Bulgakov M. The Master and Margarita. Translated by Diana Burgin and Katherine Tiernan O'Connor. London : PICADOR, 1995; Bulgakov M. The Master and Margarita. Translated by Hugh Aplin. London : Oneworld Classics, 2008; Bulgakov M. The Master and Margarita. Translated be Michael Karpelson. London : Wordsworth Classics, 2011.

2 "Night stripped away too. Behemoth's fluffy tail and his fur and scattered it in handfuls. The creature who had been the pet of the prince of darkness was revealed as a slim youth, a pagedemon, the greatest jester that there has ever been" ("The Master and Margarita", translated by Michael Glenny, 1967).

${ }^{3} \mathrm{http}: / /$ www.biblestudytools.com/job/40.html

${ }_{5}^{4} \mathrm{http} / / / \mathrm{www}$.sacred-texts.com/bib/boe/boe 063.htm

5 "Having demolished a third tangerine. Behemoth thrust his paw into an ingenious structure built of chocolate bars, pulled out the bottom one, which brought the whole thing down with a crash, and swallowed the chocolate complete with its gold wrapper". ("The Master and Margarita", translated by Michael Glenny, 1967).

${ }^{6}$ English translation of "Faust' by A.S. Kline (http://www.iowagrandmaster.org/Books\% 20in\%20pdf/Faust.pdf). In the German original we have; "Wie wird mein Pudel lang und breit!Er hebt sich mit Gewalt,Das ist nicht eines Hundes Gestalt! Welch ein Gespenst bracht' ich ins Haus! Schon sieht er wie ein Nilpferd aus,Mit feurigen Augen, schrecklichem Gebiß" (http://www.gutenberg.org/files/21000/21000-0.txt).

7 布尔加科夫，《大师与玛格丽特》，钱诚译，外国文学出版社，1987年，408页。

8 布尔加科夫, 《大师与玛加丽塔》, 高惠群译, 上海译文出版社, 2007年, 388页。

\section{References}

1. Steen G. (1994) Understanding Metaphor in Literature: an Empirical Approach. London, New York: Longman. 
2. Tolochin I.V. (1996) Metafora i intertekst v anglojazychnoj poezii: lingvostilisticheskij aspekt [The Metaphor and Intertext in the English Poetry: Linguostylistic Aspect]. SPb: Saint-Petersburg State University Press.

3. Kuzmina N.A. (2009) Intertekst: tema s variatsiyami. Fenomeny kul'tury i jazyka v intertekstual'noj interpretatsii [Intertext: A Theme with Variations. Culture and Language Phenomena through the Intertextual Interpretation]. Omsk: Omsk State University Press.

4. Averintsev S.S. (1971) Simvol khudozhestvennyj [Artistic Symbol]. Kratkaya literaturnaya entsiklopediya. Vol. 6. M.: Soviet Encyclopedia. pp. 826-831.

5. Arutyunova N.D. (1990). Metafora i diskurs [Metaphor and Discourse]. Teoriya metafory. M.: Progress. pp. 5-32.

6. The Master\&Margarita. URL: http://www.masterandmargarita. eu/en/index. html/ (Accessed: 03.02.2019).

7. Razumovskaya V.A. (2016) The Centers of Translation Attraction as the Result of Translation Plurality of the 'Strong' Original // The Russian Language in the World Context and International Organizations: International Forum. 28.09.16-3.10.16, Rome. Conference Proceedings. M.: Forum. pp. 348-356.

8. Assmann J. (1992) Das Kulturelle Gedächtnis. Schrift, Erinnerung und politische Identität in frühen Hochkulturen. München: C. H. Beck.

9. Lotman Yu.M. (1992) Pamyat' v kul'turologicheskom osveshhenii [The Memory in Culturological Aspect]. Izbrannye stat'i. Vol. 1. Tallinn: Alexandra. pp. 200-202.

10. Razumovskaya V.A. (2012) Cultural Information / Memory and Aesthetic Information in Literary Translation // Journal of Siberian Federal University. Humanities \& Social Sciences. 6. pp. 839-852.

11. Razumovskaya V.A. (2014) Translating Aboriginal Siberian and Circumpolar Cultures in Russia. Translators, Interpreters, and Cultural Negotiators Mediating and Communicating Power from the Middle Ages to the Modern Era. Eds. Federico Federici \& Dario Tessicini. London, PALGRAVE MACMILLAM. pp. 190-212.

12. Kabakchi V.V. (1998) Osnovy anglojazychnoj mezhkul'turnoj kommunikaczii [The Fundamentals of English Cross-Cultural Communication]. SPb: Herzen State Pedagogical University of Russia Press.

13. Dudareva Ya.A. (2011) Osobennosti semanticheskoj struktury slov s diffuznym znacheniem (na materiale assotsiativnogo eksperimenta so slovami sinonimami russkogo jazyka) [Specific Features of the Semantic Structure of the Words with Random Meaning (through the Example of Associative Experiment with the Synonyms in the Russian Language)] // Bulletin of Tomsk State University. 351. pp. 19-21.

14. Sharova A.A. (2010) Gendernyj aspekt zoomorfnykh obrazov (na materiale russkogo i anglijskogo jazykov) [The Gender Aspect of Zoomorphic Images (on the material of Russian and English)]. Yaroslavl: Yaroslavl State Pedagogical University. Unpublished dissertation.

15. Sokolov B.V. (2000) Bulgakovskaya entsiklopediya [The Encyclopedia of M. Bulgakov]. Moscow: Lokid; Mif.

16. Yablokov E.A. (2011) Mikhail Bulgakov i mirovaya kul'tura: Spravochnik-tezaurus. [Michail Bulgakov and the World Culture: Thesaurus]. SPb: "DMITRIY BULANIN".

17. Afanasyev A.N. (1996) Proiskhozhdenie mifa: stat'i po fol'kloru, etnografii i mifologii [The Genesis of Myth: Articles on Folklore, Ethnography, and Mythology]. M.: Indrig.

18. Ivanshina E.A. (2011) Ornitologicheskij kod pamyati v tvorchestve M.A. Bulgakova [The Ornithological Memory Code in M.A. Bulgakov's Works] // Bulletin of Udmurt University. 4. pp. 70-77.

19. Buchowski M. (1996) Metaphor, Metonymy, and Cross-Cultural Translation // Semiotica. 110. pp. 301-314.

20. Mason K. (1982) Metaphor and Translation // Babel. 28. pp. 140-149.

21. Newmark P. (1981) The Translation of Metaphor // Babel. 16. pp. 93-100. 
22. Al-Hasnawi A.R. (2007) A Cognitive Approach to Translating Metaphors // Translation Journal. 11(3). http://translationjournal. net/journal/41 metaphor.htm (Accessed: 09.02.2019).

23. Razumovskaya V.A., Yang Minbo (2012) Bulgakovskij tekst v kitajskikh perevodakh: perevodimoe i neperevodimoe [Bulgakov's Text in the Chinese Translations: Translatable and Untranslatable]. Mikhail Bulgakov, ego vremya i my. Eds. Grzegorz Przebinda / Janusz Świeży. Krakow: Spectrum. pp. 707-723.

24. Lotman Yu.M. (1998) Struktura khudozhestvennogo teksta [The Structure of Literary Text].Ob iskusstve. SPb: Iskusstvo. pp. 14-285.

25. Chang Dzhuy Cheng (2016) Metaforizacziya v khudozhestvennom tekste (na materiale proizvedenij M. Bulgakova i ikh perevodov na kitajskij jazyk) [Metaphorization in the Literary Text (on the Material of M. Bulgakov's Works and Its Chinese Translations)]. Moscow: Lomonosov Moscow State University. Unpublished dissertation.

26. Krechetova A.N., Mitchell P.J. (2016) Olitsetvoreniya zhivotnykh: trudnosti perevoda [Personification of Animals: Difficulties in Translation] // Language and Culture. 2 (34). pp. 38-44.

27. Mac Cormac E.A. (1985) Cognitive Theory of Metaphor. Cambridge (Mass): MIT Press.

28. Dagut M. (1976) More about the Translatability of Metaphor // Babel. 33(2). pp. 77-84.

29. Dagut M. (1976) Can Metaphor be Translated? // Babel. 22(1). pp. 21-33.

30. Van den Broeck R. (1981) The Limits of Translatability Exemplified by Metaphor Translation // Poetics Today. 2 (49). pp. 73-78.

31. Lakoff G., Johnson M. (1980) Metaphors We Live by. Chicago: University of Chicago Press.

32. Popova T.G., Kurochkina E.V. (2015) Metafora kak jazykovoj i mental'nyj mekhanizm v sozdanii obrazno-esteticheskoj sostavlyayushhej khudozhestvennogo proizvedeniya [Metaphor as a Language and Mental Mechanism in Artwork] // Language and Culture. 1 (29). pp. 45-53.

33. Katan D. (1999) Translating Cultures: An Introduction for Translators, Interpreters and Mediators. Manchester: St Jerome Publishing.

34. Mandelblit N. (1995) The Cognitive View of Metaphor and its Implications for Translation Theory // Translation and Meaning: 3. Maastricht: Universitaire Press. pp. 483-495.

35. Schäffner C. (2004) Metaphor and Translation: Some Application of a Cognitive Approach // Journal of Pragmatics. Amsterdam, Elsevier. 36 (7). pp. 1253-1269.

Information about the authors:

Razumovskaya V.A., Associate Professor, Candidate of Philological Sciences, Professor of Business Foreign Language Department, Institute of Economics, Management and Environmental Studies, Siberian Federal University (Krasnoyarsk, Russia). E-mail: veronica_raz@hot-mail.com

Grishaeva E.B., Associate Professor, Sc.D. (Philology), Head of Business Foreign Language Department, Institute of Economics, Management and Environmental Studies, Siberian Federal University (Krasnoyarsk, Russia).E-mail: bld_iemes@sfu-kras.ru; e-grishaeva@mail.ru 


\section{МЕТАФОРИЧНОСТЬ ХУДОЖЕСТВЕННОГО ОБРАЗА: КУЛЬТУРНАЯ ПАМЯТЬ И ПЕРЕВОД}

Разумовская Вероника Адольфовна, доцент, кандидат филологических наук, профессор кафедры делового иностранного языка Института экономики, правления и природопользования, Сибирский федеральный университет (Красноярск, Россия). E-mail: veronica_raz@hotmail.com

Гришаева Елена Борисовна, доцент, доктор филологических наук, заведующая кафедрой делового иностранного языка Института экономики, правления и природопользования, Сибирский федеральный университет (Красноярск, Россия). E-mail: bld_iemes@sfu-kras.ru; e-grishaeva@mail.ru

DOI: $10.17223 / 19996195 / 46 / 1$

Аннотация. В статье представлен комплементарный семантико-семиотический анализ художественного образа в рамках художественного текста. Анализ сопровождается постпереводческими описаниями. Будучи сформированным и функционирующим в художественном тексте, художественный образ является расширенным метафорическим образованием, предназначенным, в первую очередь, для выполнения эстетической функции. Особое внимание уделяется культурной информации и памяти, воплощенными в уникальном культурном коде, представленном в художественном образе и тесно связанном с его метафорическими характеристиками. Настоящее исследование проводилось на материале «сильного» текста русской культуры - «Мастер и Маргарита» М. Булгакова. Художественный образ булгаковского кота Бегемота представляет собой гетерогенное метафорической образование, сочетающее в себе культурную память библейского монстра Бегемота, зоометафорические характеристики бегемота (реального представителя фауны) и различные характеристики черного кота в его реальных и мифологических ипостасях. Методология исследования предполагает комплексный анализ, сочетающий мифоэпические, герменевтические и сравнительные методы. В ситуации художественного перевода художественный образ может рассматриваться как регулярная единица перевода, реконструкция которой в «чужих» языках и культурах требует специальных решений переводчика и применение эффективных методов и стратегий перевода.

Ключевые слова: «сильный» текст; художественный образ; культурная информация и память; культурный код; метафора; эстетический эффект; интертекстуальность; «Мастер и Маргарита»; Бегемот; когнитивная эквивалентность. 